\title{
Subcellular and Subnuclear Distributions of Estrogen Receptor $\alpha$ in Living Cells Using Green Fluorescent Protein and Immunohistochemistry
}

\author{
Maki Yoshida ${ }^{1,2}$, Mayumi Nishi ${ }^{1}$, Zenro Kizaki², \\ Tadashi Sawada ${ }^{2}$ and Mitsuhiro Kawata ${ }^{1}$ \\ ${ }^{1}$ Department of Anatomy and Neurobiology, Kyoto Prefectural University of Medicine, Kawaramachi-Hirokoji, \\ Kamigyo-ku, Kyoto 602-8566 and ${ }^{2}$ Department of Pediatrics, Kyoto Prefectural University of Medicine, \\ Kawaramachi-Hirokoji, Kamigyo-ku, Kyoto 602-8566
}

Received June 27, 2001; accepted September 13, 2001

\begin{abstract}
Although the subcellular localization of estrogen receptor $\alpha(E R \alpha)$ is generally recognized as in the nucleus, some studies have shown a cytoplasmic distribution. We used a time-lapse imaging technique to examine intracellular and intranuclear localizations of ER $\alpha$ using a green fluorescent protein (GFP)-ER $\alpha$ chimera protein in living COS-1 cells of different external milieu in a cultured condition. Transfected cells were treated with the ER $\alpha$ agonist, estradiol and the partial antagonist, tamoxifen, to investigate the ligand specific changes of distribution of GFP-ER $\alpha$ in a single cell. GFP-ER $\alpha$ was accumulated in the nucleus even in the absence of ligand exposure. Cells showed diffuse fine-grained
\end{abstract}

fluorescence of GFP-ER $\alpha$ in the nucleus without ligands. These results were confirmed by using anti-ER $\alpha$ antibody immunocytochemistry. GFP-ER $\alpha$ gradually and clearly formed small clusters or more punctate patterns in the nuclei of cells after ligand incubation for $60 \mathrm{~min}$, while some of the transfected cells showed a finely diffuse pattern. The manner of nuclear redistribution did not depend on the type of ligand. The present study showed that GFP-ER $\alpha$ is restricted to the nucleus and accumulates with estradiol and tamoxifen, suggesting that accumulation of ER $\alpha$ in the nucleus could be necessary for ER $\alpha$ to function with ligands.

Key words: Estrogen receptor $\alpha$, Green fluorescent protein, Subcellular distribution, Subnuclear distribution, Time-lapse imaging

\section{Introduction}

Estrogen receptor $\alpha(E R \alpha)$ is a member of the nuclear receptor superfamily and a ligand-dependent transcriptional factor mediating the physiological effects of estrogens [22]. ER $\alpha$ s are distributed in many tissues and organs; reproductive tissues [17], cardiovascular system [47], skeletal tissues [30] and central nervous system [24, 52].

The subcellular localization of steroid hormone receptors has been examined using various procedures including receptor autoradiography, immunohistochemistry and cell fractionation. Recently, intracellular trafficking of steroid hormone receptors was studied using the green fluorescent protein (GFP) in living cells showing that unoccupied gluco-

Correspondence to: Mitsuhiro Kawata, Department of Anatomy and Neurobiology, Kyoto Prefectural University of Medicine, KawaramachiHirokoji, Kamigyo-ku, Kyoto 602-8566, Japan. corticoid receptors (GRs) [18, 35, 37] and androgen receptors [12] are mainly cytoplasmic, whereas mineralocorticoid receptors [9, 34] and progesterone receptors [31] are both in the cytoplasm and nucleus, following rapid nuclear accumulation after occupation with ligands.

It had been accepted in the 1970s that the unliganded $\mathrm{ER} \alpha$ was in the cytoplasm and was translocated to the nucleus on binding to ligands via cell fractionation of the homogenated contents $[11,13]$. When immunocytochemical techniques became available, it was confirmed that ER $\alpha$ is localized in the nuclear compartment $[25,53]$. Immunoelectron microscopic studies [8, 14, 50, 53], cytochalasin B-induced enucleation procedures [49] and recent studies in living cells derived from human epithelial cell lines tagged with GFP [19] supported the nuclear localization of ER $\alpha$. However, some studies showed the low but significant cytoplasmic ER $\alpha$-immunoreactivity (IR) observed in various tissues $[1,10,23]$. One study on human breast cancer- 
derived cells, MCF-7, presented that approximately $15 \%$ of the ER $\alpha$ were retained in the cytoplasm in each cell using a cell enucleation method [48].

Intranuclear distribution of ER $\alpha$ has remained controversial. The transition of the hormonal milieu with ovariectomy [46] or estradiol $\left(\mathrm{E}_{2}\right)$ treatment [8] caused no significant differences in ultrastructural localization of ER $\alpha$-IR in in vivo reproductive and non-reproductive cells using immunoelectron microscopy, whereas redistribution of $\mathrm{ER} \alpha$ was reported in the case of cell lines visualized with GFP and its variants after ligand treatment [19, 44]. The compartmentalization of $\mathrm{ER} \alpha$ in the nucleus has been studied by immunoelectron microscopy showing ER $\alpha$-IR with a speckled pattern [53] in the dispersed euchromatin [14], in the margin of the condensed chromatin [50] and in the interchromatin space $[8,46]$.

In the present study, we investigated the time-lapse imaging of subcellular localization of GFP-ER $\alpha$ in living COS-1 cells which do not contain endogenous steroid hormone receptors using a fluorescent microscope, and, in addition, the subnuclear distribution using a confocal laser scan microscope including the time-course study. We treated the transiently transfected cells with the physiological ER $\alpha$ agonist, $E_{2}$ [42], or the synthetic partial antagonist, tamoxifen (Tam) [15] to clarify whether the receptor was redistributed in the nucleus of a single cell after ligand treatment. We also used immunocytochemistry to confirm the subcellular localization of ER $\alpha$ not only in the transfected COS- 1 cells but also in the Ishikawa cells derived from human uterine [36] and MCF-7 cells derived from human breast cancer [2], both of which express endogenous steroid hormone receptors. We present here that GFP-ER $\alpha$ is distributed in the nucleus in single COS- 1 cell in living state in the same manner as ER $\alpha$-immunoreactivity in fixed cells and accumulated regardless of ligand milieu.

\section{Materials and Methods}

\section{Plasmid construction of pEGFP-C1-ER6}

The pEGFP-C1 plasmid (Clontech, Palo Alto, CA, USA) encodes the GFPmut1 variant [5] encoding a redshifted variant of wild-type GFP with the double-amino-acid substitution of Phe-64 to Leu and Ser-65 to Thr. Expression is driven from a cytomegalovirus promoter. Rat $\mathrm{ER} \alpha(\mathrm{rER} \alpha)$ cDNA was isolated from PUC-ER6 [27] (from Dr. Koike S. and Dr. Muramatsu M., Dept. of Biochemistry, Faculty of Medicine, University of Tokyo, Saitama Medical School, Japan) by Bbe I-EcoR I digestion with blunt end formation and inserted at the Sma I site in multiple clone sites of pEGFP-C1 (Fig. 1). The C terminus of EGFP was coupled to the 59th amino acid position of the $\mathrm{N}$ terminus of $\mathrm{rER} \alpha$, resulting in $88 \mathrm{kDa}$ of fusion protein.

\section{Cell culture and transfection}

COS-1 cells were maintained in Dulbeccco's modified Eagle's medium (DMEM) (Gibco BRL, CergyPontoise, France) supplemented with $10 \%$ fetal calf serum (FCS)



Fig. 1. Construction of GFP-ER $\alpha$ expression plasmid. The N-terminal truncated $\mathrm{rER} \alpha$ cDNA (Bbe I-Eco RI) was inserted at the Sma I site in the multiple clone site downstream of the EGFP.

and kanamycin. For transfection, semiconfluent cells were resuspended at $2 \times 10^{4}$ cells in DMEM into each well of a Multidish (Nunc, Naperville, IL, USA) for fluorescence microscopy analysis, and at $1.6 \times 10^{4}$ cells onto the glass at the bottom of the Glass-bottom dish (MATSUNAMI, Osaka, Japan) for confocal laser scan microscopy analysis. Cells were grown for $24 \mathrm{hr}$, and transfected by LIPOFECTAMINE PLUS reagent (Gibco BRL) following the manufacturer's protocols with some modification using $300 \mathrm{ng}$ of the pEGFP-C1-ER6 or pEGFP-C1 plasmid for the Multidish and $115 \mathrm{ng}$ for the Glass-bottom dish per well for $5 \mathrm{hr}$ at $37^{\circ} \mathrm{C}$. After removing the DNA medium, cells were incubated for $4 \mathrm{hr}$ with OPTI-MEM I (Gibco BRL) containing $10 \%$ charcoal-stripped FCS. The medium was then replaced and cells were grown with OPTI-MEM I without serum for $12-18 \mathrm{hr}$ until imaging.

\section{Characterization of GFP-ER $\alpha$}

Immunocytochemistry of COS-1 cells with anti-GFP or antiER $\alpha$ antibody

COS-1 cells transfected with pEGFP-C1-ER6 or pEGFP-C1 were fixed with $4 \%$ paraformaldehyde in phosphate-buffered saline (PBS) at $\mathrm{pH} 7.4$ for $10 \mathrm{~min}$ at $37^{\circ} \mathrm{C}$. The fixed cells were incubated in the PBS containing $0.2 \%$ Triton X-100 and $2 \%$ bovine serum albumin to permeabilize and prevent nonspecific staining for $60 \mathrm{~min}$ at room temperature (RT). Cells were subsequently incubated with the monoclonal anti-GFP antibody produced by mouse hybridoma cells (Clontech) diluted to 1:3,000 or the polyclonal anti-rat ER $\alpha$ antibody raised in a rabbit (AS409, from Dr. Hayashi S., Yokohama City University, Faculty of Science, Japan) [38] diluted to $1: 2,000$ with PBS for $40 \mathrm{hr}$ at $4^{\circ} \mathrm{C}$. They were further incubated with the biotinylated goat antimouse or anti-rabbit IgG $(7.5 \mu \mathrm{g} / \mathrm{ml}$; Vector Laboratories, 
Burlingame, CA, USA) in PBS for $2 \mathrm{hr}$ at RT, and then with the avidin-biotin complex solution (Vector Laboratories) for $1 \mathrm{hr}$ at RT. After the last wash with PBS, cells were reacted for $3 \mathrm{~min}$ at RT with a solution containing $0.2 \mathrm{mg} / \mathrm{ml} \mathrm{3',3'-}$ diaminobenzidine tetrahydrochloride and $0.006 \% \mathrm{H}_{2} \mathrm{O}_{2}$ in $50 \mathrm{mM}$ Tris- $\mathrm{HCl}, \mathrm{pH}$ 7.4. They were washed and analyzed under a light microscope. COS-1 cells without transfection were employed for the immunostaining with anti-GFP or anti-ER $\alpha$ antibody following the same procedure.

\section{Western blot analysis}

COS- 1 cells were resuspended at $2.5 \times 10^{5}$ cells per $2 \mathrm{ml}$ in DMEM into the dishes (FALCON, Franklin Lakes, NJ, USA) and transfected with $1.44 \mu \mathrm{g}$ of pEGFP-C1-ER6 or pEGFP-C1. Cells were solubilized in $500 \mu$ l of $3 \times$ sample buffer (195 mM Tris-HCl, pH 6.8, 9.156\% SDS, 15\% 2mercaptoethanol, $30 \%$ glycerol, $0.0075 \%$ bromophenol blue). Proteins were denatured by boiling for $5 \mathrm{~min}$, separated via SDS/12.5\% PAGE and transferred to polyvinylidene difluoride membrane (Immunobilon-P, Millipore, Bedford, MA, USA). Blots were blocked in $2.5 \%$ skimmed milk (DIFCO, Detroit, MI, USA) in Tris buffered saline-polyoxyethylene sorbitan monolaurate (Tween 20) (TBST; $0.02 \mathrm{M}$ Tris, $1.5 \mathrm{M} \mathrm{NaCl}, 0.05 \%$ Tween-20, $\mathrm{pH}$ 7.6) for $90 \mathrm{~min}$ followed by antibody incubation with anti-GFP serum diluted to $1: 3,000$ and anti-ER $\alpha$ serum (AS409) diluted to 1:2,000 for $20 \mathrm{hr}$ at $4^{\circ} \mathrm{C}$. After washing with TBST, membranes were incubated with horseradish peroxidase-linked secondary antibody diluted to 1:5,000 with TBST for $1 \mathrm{hr}$ at RT. An enhanced chemiluminescence detection technique (Amersham, le Ulis, France) was used.

\section{Transcription regulation study}

COS- 1 cells were seeded at $1.0 \times 10^{5}$ cells per $2 \mathrm{ml}$ in DMEM into the dishes (FALCON). The reporter plasmid, estrogen response element (ERE)-G-Luc (from Maruyama K., Institute for Drug Discovery Research, Yamanouchi Pharmaceutical Co., Ltd., Japan) [32], has the construction as below; Rabbit $\beta$-globin TATA box $(-40$ to +10$)$ was introduced into the upstream region of the luciferase gene of the pGL2-basic vector (Promega, Madison, WI, USA), and a palindromic estrogen responsive element (ERE, AGGTCACAGTGACCT) was fused upstream from the TATA box. Cells were transfected with $1 \mu \mathrm{g}$ of each pEGFPC1-ER6, ERE-G-Luc and pCH110, a $\beta$-galactosidase reporter (Pharmacia, Uppsala, Sweden). After removing the DNA medium, cells were incubated for $4 \mathrm{hr}$ with OPTI-MEM I containing $10 \%$ DCC-FCS and then containing 2\% DCCFCS. After $12 \mathrm{hr}$, cells were washed and replaced with fresh OPTI-MEM I without serum with or without $1 \mu \mathrm{M} \mathrm{E} \mathrm{E}_{2}$. After $24 \mathrm{hr}$, cells were lysed to determine luciferase and $\beta$-galactosidase activity by PicaGene Reporterlysis Buffer (Toyo Inki, Tokyo, Japan). For luciferase activity, the extracts were assayed with a New Reporter Gene Luciferase Assay System PicaGene kit (Toyo Inki) and were normalized to the $\beta$-galactosidase activity analyzed with a Luminescent $\beta$ galactosidase Detection Kit (Clontech) following the manu- facturer's protocols.

\section{Fluorescence microscopy analysis}

Transfected cells were treated with either $1 \mathrm{nM} \mathrm{E}_{2}$ or $50 \mathrm{nM}$ Tam, at approximately ten-fold higher concentrations than the dissociation constant of ER $\alpha$ for each ligand [29], and the images of identical cells were acquired before and 60 min after treatment. Cells were soaked in $300 \mathrm{ng} / \mathrm{ml}$ bisbenzimide (Hoechst No. 33342, Sigma, St. Louis, MO, USA) to visualize nuclei and then observed with a $40 \times$ objective lens. GFP fluorescence was viewed by excitation with transmission through a 460- to 490-nm band pass filter and an emission peak transmission at the 515-nm line. The fluorescence from the staining with Hoechst 33342 was observed using the excitation filter with the transmission through a 330- to 385-nm band pass filter and an emission peak at $420 \mathrm{~nm}$. Fluorescence images were acquired on a SenSys 1400 high-resolution, cooled charge-coupled device (CCD) camera (Photometrics, Tucson, AZ, USA) attached to the fluorescence microscope (IX70, Olympus, Tokyo, Japan) set in the dark room kept at $37^{\circ} \mathrm{C}$ during analysis, as described in detail previously [35]. Images were evaluated using IPLab Spectrum software (Signal Analytics Corporation, Vienna, Austria).

\section{Time-lapse confocal laser scan microscopy analysis}

Transfected COS-1 cells were treated with either $1 \mathrm{nM}$ $\mathrm{E}_{2}$ or $50 \mathrm{nM}$ Tam. Just before and $60 \mathrm{~min}$ after treatment with ligands, they were imaged through a $60 \times 1.4$ numerical aperture Plan Apochromat oil immersion objective attached to an inverted microscope (ECLIPSE TE300, Nikon, Tokyo, Japan) by excitation with a 488-nm line from a kryptonargon laser, and the emission was viewed through a 500-nm long pass filter. Images were collected with Radiance 2000 (Bio-Rad, Hercules, CA, USA) using LaserSharp 2000 software (Bio-Rad). For the time course analysis, images were captured every 10 or $15 \mathrm{~min}$ for $60 \mathrm{~min}$ after ligand treatment. The analyses of the images from the confocal laser scan microscope were performed using NIH Image program version 1.61. To obtain line graphs, pixel values for each area along the lines of major or minor axes scanned on the captured cells were divided.

\section{Immunocytochemistry of Ishikawa cells and MCF-7 cells with anti-ER $\alpha$ antibody}

Ishikawa cells and MCF-7 cells were maintained in modified Eagle's medium (MEM) (Biken, Osaka, Japan) supplemented with $10 \%$ fetal calf serum (FCS) and Antibiotic-Antimycotic (Gibco BRL). Cells were fixed and immunostained with the anti-rat $\operatorname{ER} \alpha$ antibody (AS409) diluted to $1: 1,000$. The same procedure was performed with the COS-1 cells. Other dishes of each kind of cells were omitted from the reaction with anti-rat ER $\alpha$ antibody serum for the negative control. 


\section{Results}

\section{Characterization of GFP-ER $\alpha$}

Immunocytochemistry of COS-1 cells with anti-GFP or antiER $\alpha$ antibody

The immunocytochemistry findings with anti-GFP antibody demonstrated both cytoplasmic and nucleoplasmic IRs in COS-1 cells transfected with pEGFP-C1 alone (Fig. 2Ab), whereas dense nuclear labelings, except nucleoli, were seen in the pEGFP-C1-ER6-transfected cells (Fig.
2Ac). COS-1 cells transfected with pEGFP-C1 alone did not show any ER $\alpha$-labeling (Fig. 2Ae), and in the cells expressing GFP-ER $\alpha, \mathrm{ER} \alpha$-IR was detected only in the nuclei, not in the cytoplasm (Fig. 2Af). In the nucleus, ER $\alpha$-IR was not present in the nucleoli. Cells without transfection showed no GFP- (Fig. 2Aa) or ER $\alpha$-IR (Fig. 2Ad).

\section{Western blot}

Western blot analysis employing the anti-GFP antibody and anti-ER $\alpha$ antibody exhibited a major band at the posi-
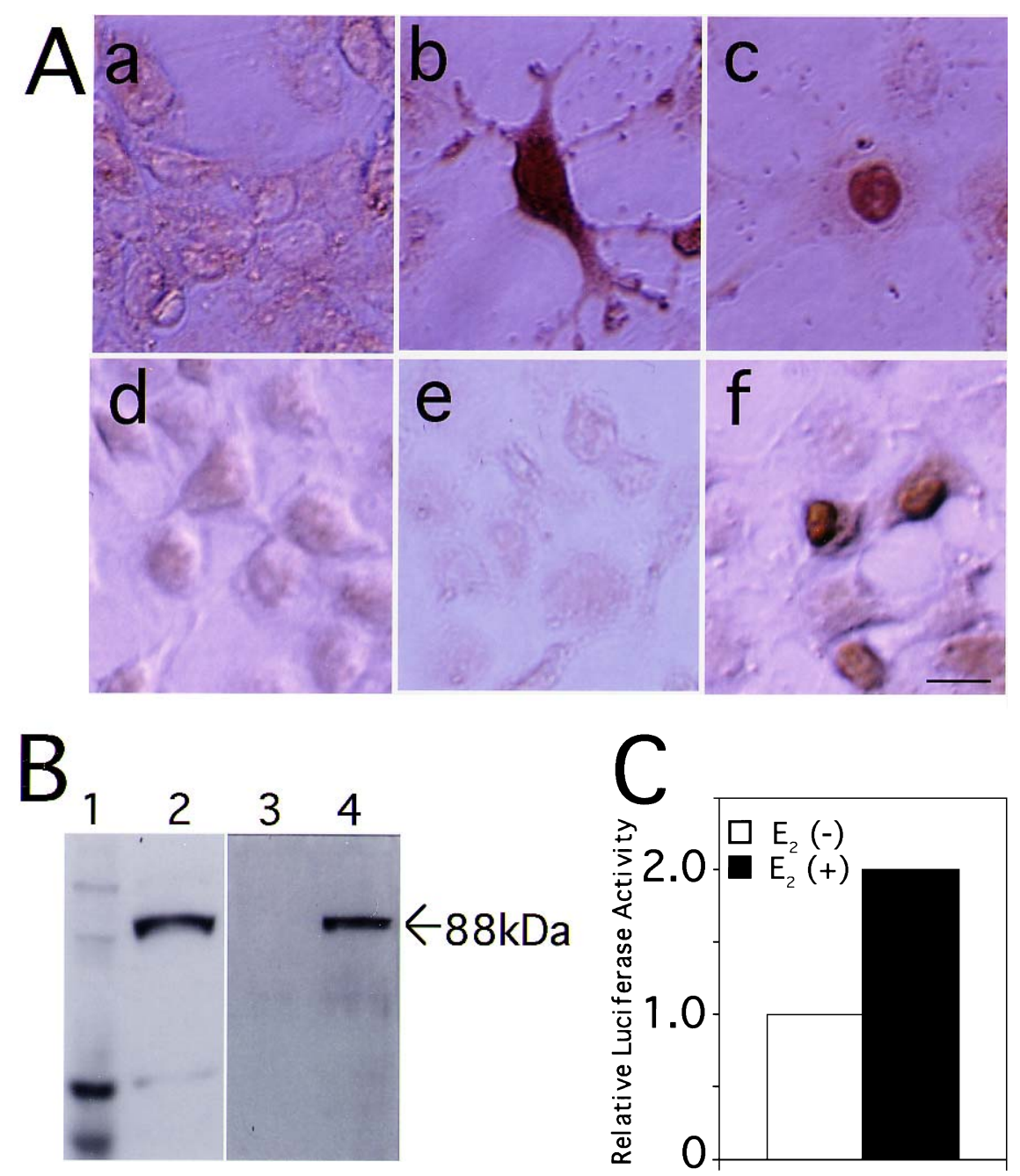

Fig. 2. Characterization of GFP-ER $\alpha$. (A) Immunocytochemistry of COS- 1 cells with anti-GFP or anti-ER $\alpha$ antibody. (a)-(c) show the cells reacted with anti-GFP antibody, and (d)-(f), with anti-ER $\alpha$ antibody. (a) and (d) are COS-1 cells without transfection, (b) and (e) are COS-1 cells transfected with pEGFP-C1, and (c) and (f) are transfected with pEGFP-C1-ER6. Both nuclear and cytoplasmic GFP-IR are presented in the cell expressing GFP (b), whereas distinct nuclear IR was detected by both anti-GFP and anti- ER $\alpha$ reaction in the cells transfected with GFP$\mathrm{ER} \alpha(\mathbf{c}, \mathbf{f}) . \mathrm{Bar}=20 \mu \mathrm{m}$. (B) Western blot analysis of protein products of pEGFP-C1 and pEGFP-C1-ER6 expressed in COS-1 cells. Lanes 1 and 3 contained extracts from GFP-transfected COS-1 cells, and lanes 2 and 4, from GFP-ER $\alpha$-transfected cells. Lanes 1 and 2 were analysed using anti-GFP antibody, and lanes 3 and 4, anti-ER $\alpha$ antibody. With both anti-GFP and anti-ER $\alpha$ antibody, expressed GFP-ER $\alpha$ was detected with a major band at $88 \mathrm{kDa}$ in lanes 2 and 4, whereas expressed GFP was not detected with any band at the sight of the same molecular mass. (C) Transcriptional activity of the GFP-ER $\alpha$ in COS- 1 cells was induced after incubation with $1 \mu \mathrm{M} \mathrm{E}_{2}$ for $24 \mathrm{hr}$. Promoter plasmid, ERE-G-Luc, and $\beta$-galactosidase reporter plasmid, pCH110, were cotransfected with pEGFP-C1-ER6. Luciferase activity was normalized using $\beta$-galactosidase activity and expressed as relative luciferase activity (R. L. A.). R. L. A. was plotted regarding the induction obtained with GFP-ER $\alpha$ without $\mathrm{E}_{2}$ as 1.0. The ratio of GFP-ER $\alpha$ activity with the induction by $\mathrm{E}_{2}$ to the activity without any induction was 2.0. 
tion of the expected molecular mass, $88 \mathrm{kDa}$, on the lanes blotted with the GFP-ER $\alpha$ chimera protein expressed in the COS-1 cells (Fig. 2B lanes 2 and 4). The cells transfected with pEGFP-C1 showed the band at the $27 \mathrm{kDa}$ site representing EGFP with the anti-GFP antibody (the band of EGFP is out of the section of lane 1 shown in Fig. 2B), but no bands were detected at the $88 \mathrm{kDa}$-site with anti-GFP or anti-ER $\alpha$ antibody (Fig. 2B lane 1,3).

\section{Transcription regulation study}

PEGFP-C1-ER6 expressing the GFP-ER $\alpha$ chimera protein, plasmid ERE-G-Luc and pCH110 for normalization using $\beta$-gal activity, were cotransfected into COS- 1 cells. Ligand-dependent induction of the ERE was 2-fold greater than the noninduced relative luciferase activity by GFP-ER $\alpha$
(Fig. 2C). We confirmed that the transcriptional activation of the GFP-ER $\alpha$ chimera protein was functionally maintained despite the presence of GFP.

\section{Fluorescence microscopy with a cooled CCD camera}

We examined pEGFP-C1-ER6-transfected samples for subcellular distribution of the GFP-ER $\alpha$ chimera protein comparing with the localization of the GFP protein using pEGFP-C1-transfected cells. A cell expressing GFP alone exhibited green fluorescence in both the nucleus and cytoplasm (Fig. 3Ab), whereas diffuse GFP-ER $\alpha$ fluorescence constituting fine particles was restricted to the nucleus, except the nucleoli, of transfected cells (Fig. 3Bc). The region of nucleus was confirmed by Hoechst 33342 staining (Fig. $3 \mathrm{Bb})$. To investigate the ligand-inducible nucleocytoplasmic
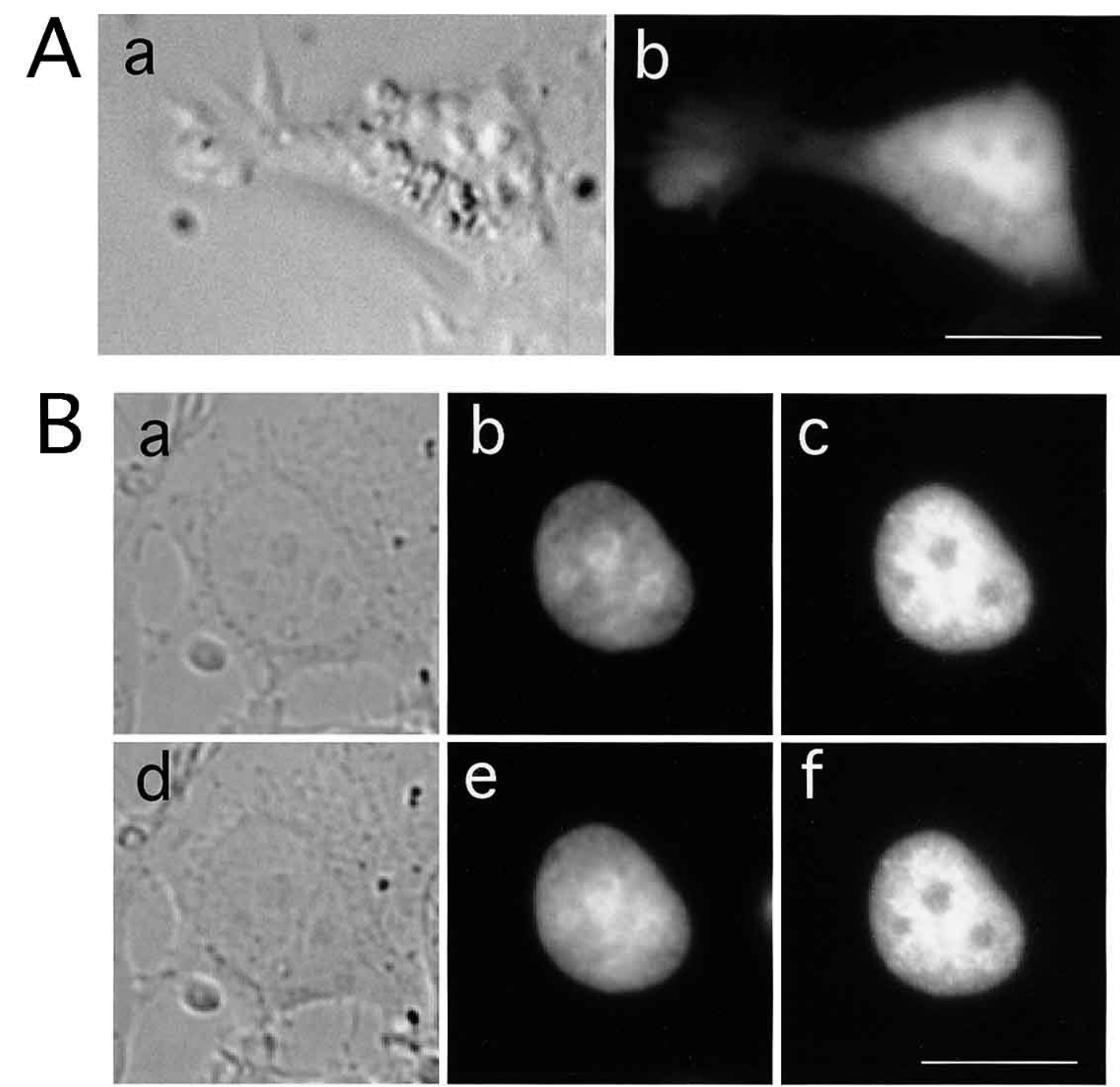

Fig. 3. Subcellular distribution of GFP and GFP-ER $\alpha$ in COS-1 cells using a fluorescence microscope. (Aa), (Ba) and (Bd) are the images with Nomarski differential interference contrast, $(\mathbf{B b})$ and $(\mathbf{B e})$ are the figures stained with Hoechst 33342, and (Ab), (Bc) and (Bf) are green fluorescent images. (A) and (B) are two single cells respectively. (A) is the cell expressing GFP. GFP is distributed in both the nucleus and cytoplasm (Ab). (B) is the cell expressing GFP-ER $\alpha$. (Ba)-(Bc) were acquired before adding $1 \mathrm{nM} \mathrm{E}$, and (Bd)-(Bf), 60 min after adding. Nuclear diffuse fluorescence of GFP-ER $\alpha$ was detected, except for the nucleoli, and not in the cytoplasm (Bc, Bf). Exposure to $E_{2}$ did not lead to any nucleocytoplasmic trafficking (Bf). Bar $=20 \mu \mathrm{m}$. 
trafficking, we imaged the cells expressing GFP-ER $\alpha$ before and $60 \mathrm{~min}$ after adding $1 \mathrm{nM}$ agonist $\mathrm{E}_{2}$ in a single living cell. Sixty minutes after $\mathrm{E}_{2}$ treatment, GFP-ER $\alpha$ remained in the nucleus (Fig. 3Bf). We applied $50 \mathrm{nM}$ partial antagonist, Tam, to the cells expressing GFP-ER $\alpha$, and no apparent translocation of the fluorescence from the nucleus to the cytoplasm was observed as shown in the case of $E_{2}$ treatment. A 100-fold higher concentration of ligands, $10 \mathrm{nM} \mathrm{E}_{2}$ or $5 \mu \mathrm{M}$ Tam was applied to transfected cells, but trafficking of GFP-ER $\alpha$ was not observed (data not shown).

\section{Time-lapse confocal laser scanning microscopy}

Transfected COS-1 cells were subjected to time-lapse imaging using a confocal laser scanning microscope to investigate spatiotemporal subnuclear distribution of GFP$\mathrm{ER} \alpha$. Before the exposure to ligands, green fluorescence


Fig. 4. Time-lapse image analysis of subnuclear distribution of GFP-ER $\alpha$ in COS- 1 cells exposed $1 \mathrm{nM} \mathrm{E} \mathrm{E}_{2}$ for 60 min using a confocal laser scan microscope. (A) is the image of GFP-ER $\alpha$-fluorescence of a single cell. (B) shows the graphs of pixel values along the lines a-d. (Ba) is for the line $\mathbf{a}$ and $(\mathbf{B b})$ is for the line $\mathrm{b}$ on the untreated nucleus $(\mathbf{A}, 0 \mathrm{~min})$, and $(\mathbf{B c})$ is for the line $\mathrm{c}$ and $(\mathbf{B d})$ is for the line $\mathrm{d}$ on the nucleus $60 \mathrm{~min}$ after $\mathrm{E}_{2}$ treatment $\left(\mathrm{A}, 60 \mathrm{~min}\right.$ ). (A) In the absence of $\mathrm{E}_{2}$, GFP-ER $\alpha$ was composed of small specks diffusely dispersed in the nucleus, except the nucleoli (A, $0 \mathrm{~min}$ ), which gradually changed to a punctate distribution of distinct fluorescence over time (A, 10, 25, 40, $50 \mathrm{~min})$. GFP-ER $\alpha$ constituted small prominent clusters $60 \mathrm{~min}$ after the treatment $(\mathbf{A}, 60 \mathrm{~min})$. (B) Before $\mathrm{E}_{2}$ treatment, the graph showed a small amplitude and a rather smooth transition $(\mathbf{B a}, \mathbf{b})$. The pixel values markedly fluctuated up and down $60 \mathrm{~min}$ after the treatment $(\mathbf{B c}, \mathbf{d})$. Bar=20 $\mu \mathrm{m}$. 


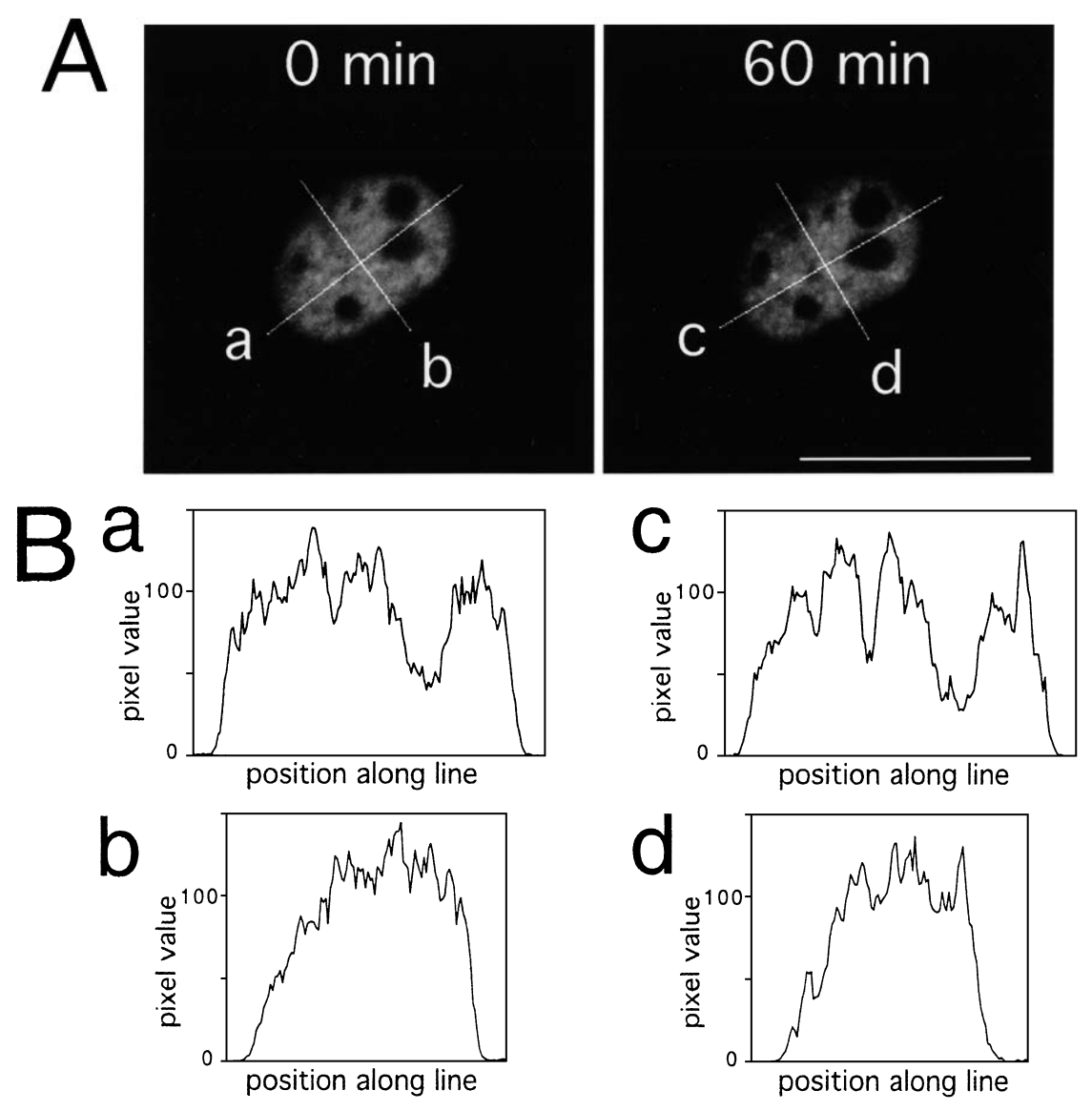

Fig. 5. Subnuclear distribution of GFP-ER $\alpha$ in COS- 1 cells before and after exposure to $50 \mathrm{nM}$ Tam for 60 min using a confocal laser scan microscope. (A) is the image of GFP-ER $\alpha$-fluorescence of a single cell. (B) shows the graphs of pixel values along the lines a-d. (Ba) is for the line $\mathbf{a}$ and $(\mathbf{B b})$ is for the line $\mathrm{b}$ in the untreated nucleus $(\mathbf{A}, 0 \mathrm{~min})$, and $(\mathbf{B c})$ is for the line $\mathbf{c}$ and $(\mathbf{B d})$ is for the line $\mathrm{d}$ in the nucleus $60 \mathrm{~min}$ after Tam treatment (A, $60 \mathrm{~min}$ ). (A) In the absence of Tam, GFP-ER $\alpha$ was composed of small specks diffusely dispersed in the nucleus, except the nucleoli (A, 0 min). Sixty min after the exposure, GFP-ER $\alpha$ formed prominent speckles in the nucleus (A, 60 min). (B) The graphs $60 \mathrm{~min}$ after treatment show the transitional pixel values with a larger amplitude and spiky notches $(\mathbf{B c}, \mathbf{d})$ compared with the graph before treatment $(\mathbf{B a}, \mathbf{b})$. Bar $=20 \mu \mathrm{m}$.

was found diffusely in a fine-grained distribution in the nucleus, except in the nucleoli (Fig. 4A, 0 min, Fig. 5A, 0 min). However, the size or the intensity of the fine speckles did not show complete uniformity in individual cells (data not shown). Incubation with $1 \mathrm{nM} \mathrm{E}_{2}$ induced more punctate features of green fluorescence in a time dependent manner (Fig. 4A, 10, 25, 40, $50 \mathrm{~min}$ ). Sixty min after $\mathrm{E}_{2}$ addition, GFP$\mathrm{ER} \alpha$ was redistributed in the nucleus to form small clusters with more discrete accumulation, except in the nucleoli, than in the absence of $E_{2}$ (Fig. 4A, $60 \mathrm{~min}$ ). We traced the pixel values for fluorescence intensity along the lines from left to right or top to bottom settled as major or minor axes on images of the single cell at the time before and $60 \mathrm{~min}$ after $\mathrm{E}_{2}$ treatment (Fig. 4A line a-d) and constructed line graphs to analyze the ligand-induced subnuclear localization change of GFP-ER $\alpha$ (Fig. 4B). The pixel values of the lines on the cell (Fig. 4A line a, b) shaped the transition pattern with a small and rather uniform amplitude in the untreated nucleus (Fig. 4Bab). Sixty min after the treatment, the fluorescent intensity along the lines (Fig. 4A line c, d) robustly changed with the greatest magnitude reflecting the punctate distribution of GFP-ER $\alpha$ (Fig. 4Bcd). We also exposed the cells to $50 \mathrm{nM}$ Tam to examine the subnuclear redistribution of GFP-ER $\alpha$ using the same procedure as in the case of $E_{2}$ and analyzed the images before and $60 \mathrm{~min}$ after the Tam treatment (Fig. 5A). Cells formed the prominent speckles of green fluorescence in the nuclear region compared to the absence of Tam (Fig. 5A, $60 \mathrm{~min}$ ). The transition feature of the fluorescent intensity along the traced lines in the cells 60 min after Tam treatment (Fig. 5A line c, d) presented more intensely up-and-down transition (Fig. 5Bcd) than before treatment (Fig. 5Bab) along the lines $a$ and b (Fig. 5A). These transformations mirrored the conspicuous change to a more punctated redistribution. The pixel value was markedly lowered in the region of the nucleoli and recovered outside the nucleoli (Fig. 5B). It was unclear whether the subnuclear redistribution pattern of GFP-ER $\alpha$ was different between the kind of ligands, $\mathrm{E}_{2}$ and Tam (Fig. 4A, 60 min, Fig. 5A, 60 min). 


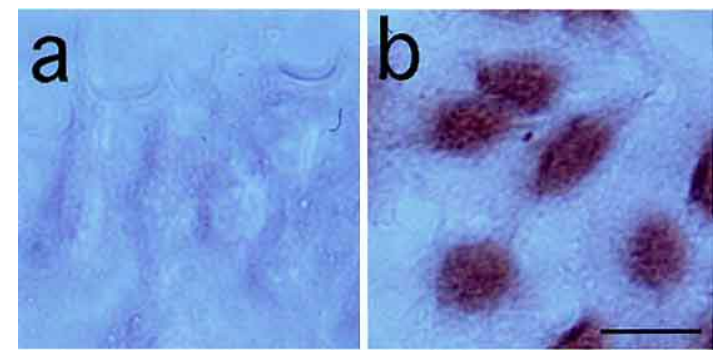

Fig. 6. Immunocytochemistry of Ishikawa cells with anti-ER $\alpha$ antibody. (a) is the cells omitted from the reaction with anti-ER $\alpha$ antibody and (b) shows the cells incubated with antibody. ER $\alpha$-IR was detected in the nuclei and not in the cytoplasms in Ishikawa cells (b). $\operatorname{Bar}=40 \mu \mathrm{m}$.

\section{Immunocytochemistry of Ishikawa cells and MCF-7 cells with anti-ER $\alpha$ antibody}

Specific nuclear staining for ER $\alpha$-IR was restricted within the nuclei and cytoplasmic staining was absent in both Ishikawa cells (Fig. 6) and MCF-7 cells containing endogenous ER $\alpha$. The distribution features of ER $\alpha$-IR in Ishikawa cells and MCF-7 cells were the same as those observed in the COS- 1 cells. In contrast, ER $\alpha$ immunostaining was not shown in cells without incubation with anti-ER $\alpha$ serum.

\section{Discussion}

Intracellular distribution of $\mathrm{ER} \alpha$ has been investigated using diverse procedures which showed different results depending on the methods; cytoplasmic distribution of unliganded receptor with nuclear translocation after adding ligands [11, 13], and cytoplasmic recognition with nuclear dominance $[1,10,23]$, although the idea of the restriction in the nucleus is now most widely accepted $[8,14,25,50,53]$. In this study, we presented the nuclear localization of ER $\alpha$ with immunocytochemical procedure in fixed cells expressing endogenous $\mathrm{ER} \alpha$, Ishikawa cells derived from human endometrial adenocarcinoma [36] and MCF-7 cells from human breast carcinoma [2]. Special features on the performance of each method could explain the discrepancies. The method of cell fractionation requires homogenization, which may have induced the finding that unliganded $\mathrm{ER} \alpha$ was loosely associated with the nuclear matrix detected in the cytosol fraction, but liganded ER $\alpha$ was detected in the nuclear fraction with the tight association [14]. Immunoreactive techniques require many steps and long periods for reactions. Buchenau et al. [3] presented striking differences in the distribution of heterogeneous nuclear ribonucleoprotein (hnRNP) K protein, one of the proteins composing hnRNP complexes [28], of living cells compared with fixed preparations. This inconsistency is considered to be caused by the changes of the chromatin structure, the change of the association with transcription sites by fixation, or the flexibility of transcriptional sites in living cells. Some nuclear receptors were depicted in a dissimilar nucleocytoplasmic dis- tribution; progesterone receptor- [16] and thyroid receptorIR [40] were detected in nuclei alone, whereas their fusion protein with GFP were found not only in the nuclei but also in the cytoplasm in certain ratios $[31,54]$. We investigated the subcellular and subnuclear distribution using GFP fusion protein because GFP enabled visualization in a single living cell without fixation and permeabilization. The properties of the GFP-ER $\alpha$ chimera protein were confirmed with immunocytochemistry, western blot analysis and a transcription regulation study. The cells were not deteriorated during the entire course of microscopic observation.

The present findings showed that GFP-ER $\alpha$ chimera protein was localized in the nucleus even in the absence of ligands. Nucleocytoplasmic transport of proteins larger than $45 \mathrm{kDa}$ is regulated through the nuclear pore complex by recognizing nuclear localization signals (NLS) [21]. A number of proteins possessing NLSs are predominantly cytoplasmic due to the inaccessibility or masking of their NLSs, which interact with other proteins or induce conformational change to translocate the proteins to the nucleus [21]. ER $\alpha$ owns four motifs of NLSs; a ligand-inducible NLS is in region $\mathrm{E}$ (hormone binding domain), and the other three are in region $\mathrm{C}$ (DNA binding domain) and region $\mathrm{D}$. These NLSs, except for the ligand-inducible one, are not masked in the absence of ligands [51], which supports the finding in the present investigation of the nuclear restriction of GFP-ER $\alpha$.

GFP-ER $\alpha$ formed fine speckles in the absence of ligands and small clusters in the presence of ligands in the present study. The constituent of ER $\alpha$-containing structures within the nuclei is one of the major topics of this area. It has been shown that ER $\alpha$ was localized in the chromatin in several immunoelectron microscopy studies, although its specificity in the chromatin, in the euchromatin [14] or in the margin of the condensed chromatin [50], has not been clarified. Another study reported its detection in the interchromatin space [46], which suggests the participation of certain protein factors in the nuclear matrix. HnRNP is one of the candidates composing the compound of ER $\alpha$ in the nuclei [46]. More than 20 different proteins are involved in hnRNP complex [28]; some of the components were revealed by dotted nucleoplasmic staining, excluding the nucleoli $[3,7$, 33]. Further more, previous studies reported the relation between ER $\alpha$ and protein complexes in the nuclei, such as SWI2/SNF2 [4, 20]. This complex is one of the proteins of the SWI/SNF complex facilitating the binding of activator proteins to nucleosomal DNA in an ATP-dependent way [6] and helping the transcriptional activator to overcome chromatin-mediated repression [26]. Confocal microscopic observation of the SWI/SNF complex revealed a diffuse nucleoplasmic labeling and a variable number of bright dots or foci [41]. The studies on the distributions of hnRNP and SWI2/SNF2 support the present findings of reticular or punctate nuclear signals of GFP-ER $\alpha$. Considering the coexistence or interaction with chromatin, hnRNP or SWI2/ $\mathrm{SNF} 2$, fine or dotted accumulation of ER $\alpha$ in the nuclei, may be actively engaged in the transcriptional function of the nuclear receptor. Htun et al. presented the distinct sub- 
nuclear localization of agonist-bound, as opposed to antagonist-bound GR and suggested a functionally distinct subnuclear population [18]. In contrast, the clusters of GR are reported to lack a relation to the site of active transcription [43]. The significance of the speckle or cluster formation including nuclear $\mathrm{ER} \alpha$ is the ultimate question but requires cautious investigations.

Before the exposure to ligands, GFP-ER $\alpha$ was distributed within the nuclei in a fine-grained or speckled pattern, and the size, number, or intensity of the fluorescence was not completely uniform in each cell, although all cells from a single cell line were treated similarly. The activity of the intake of the transgene and its expression cannot be unified in transient transfection, which is affected by the phase of the cell cycle [45]. In addition to the disparity of the amount of chimera protein produced from the transfected gene, the components of the matrix with a cell cycle-specific distribution, such as hnRNP [7] coexisting with GFP-ER $\alpha$, may cause the diversity in the subnuclear distribution of GFP$\mathrm{ER} \alpha$ separate from the effect of the ligands. The strategy that the GFP-ER $\alpha$ chimera protein is consistently expressed in cells whose cycles are synchronized will lead to more precise explanation.

Treatment with ligands, $\mathrm{E}_{2}$ or Tam, induced nuclear redistribution in some cells to a more punctate pattern compared with cases without ligands. Ligands may cause the change in the compartment factors bound to GFP-ER $\alpha$, such as coactivators or corepressors, and may redistribute GFPER $\alpha$ s. It is also possible that the ligand-inducible translocation of GFP-ER $\alpha$ to the site of the chromatin was engaged in transcription.

Tamoxifen, one of the selective estrogen modulators, exhibits estrogen agonist effects in many organs and is widely used in the treatment of breast cancer. However, it stimulates uterine tissue as an antagonist and activates the promotor possessing activating protein 1 element [39]. The partial antagonist, Tam, and physiological agonist, $\mathrm{E}_{2}$, differ in their function via $\mathrm{ER} \alpha$, but these two compounds did not reveal different translocations of GFP-ER $\alpha$. Further investigation with various ligands or hormones is anticipated to elucidate the significance of the variety of the intracellular distribution of ER $\alpha$.

In conclusion, we have made the real-time analysis of the GFP-ER $\alpha$ possible in a single living cell. Our study showed that the GFP-ER $\alpha$ restricted to the nucleus and ligands exposure changed the distributions of this chimera protein to a punctate pattern. This system of investigation will contribute to the explanation of the intracellular dynamics of ER $\alpha$ and the mechanism of transcription induced with $\mathrm{ER} \alpha$.

\section{References}

1. Blaustein, J. D., Lehman, M. N., Turcotte, J. C. and Greene, G.: Estrogen receptors in dendrites and axon terminals in the guinea pig hypothalamus. Endocrinology 131; 281-290, 1992.

2. Brooks, S. C., Locke, E. R. and Soule, H. D.: Estrogen receptor in a human cell line (MCF-7) from breast carcinoma. J. Biol. Chem. 248; 6251-6253, 1973.

3. Buchenau, P., Saumweber, H. and Arndt-Jovin, D. J.: The dynamic nuclear redistribution of an hnRNP K-homologous protein during Drosophila embryo development and heat shock. Flexibility of transcription sites in vivo. J. Cell Biol. 137; 291-303, 1997.

4. Chiba, H., Muramatsu, M., Nomoto, A. and Kato, H.: Two human homologues of Saccharomyces cerevisiae SWI2/SNF2 and Drosophila brahma are transcriptional coactivators cooperating with the estrogen receptor and the retinoic acid receptor. Nucleic Acids Res. 22; 1815-1820, 1994.

5. Cormack, B. P., Valdivia, R. H. and Falkow, S.: FACS-optimized mutants of the green fluorescent protein (GFP). Gene 173; 33-38, 1996.

6. Cote, J., Quinn, J., Workman, J. L. and Peterson, C. L.: Stimulation of GAL4 derivative binding to nucleosomal DNA by the yeast SWI/SNF complex. Science 265; 53-60, 1994.

7. Dejgaard, K., Leffers, H., Rasmussen, H. H., Madsen, P., Kruse, T. A., Gesser, B., Nielsen, H. and Celis, J. E.: Identification, molecular cloning, expression and chromosome mapping of a family of transformation upregulated hnRNP-K proteins derived by alternative splicing. J. Mol. Biol. 236; 33-48, 1994.

8. Echeverria, O. M., Maciel, A. G., Traish, A. M., Wotiz, H. H., Ubaldo, E. and Vazquez-Nin, G. H.: Immuno-electron microscopic localization of estradiol receptor in cells of male and female reproductive and non-reproductive organs. Biol. Cell 81; 257-265, 1994

9. Fejes-Toth, G., Pearce, D. and Naray-Fejes-Toth, A.: Subcellular localization of mineralocorticoid receptors in living cells: effects of receptor agonists and antagonists. Proc. Natl. Acad. Sci. U S A 95; 2973-2978, 1998.

10. Fox, C. A., Ross, L. R., Handa, R. J. and Jacobson, C. D.: Localization of cells containing estrogen receptor-like immunoreactivity in the Brazilian opossum brain. Brain Res. 546; 96-105, 1991.

11. Geier, A., Cocos, M., Ginzburg, R., Haimsohn, M. and Lunenfeld, B.: Estradiol binding to nuclear receptors in human breast cancer tissue (MCF-7) and in dimethylbenz(a)anthraceneinduced mammary carcinoma. J. Clin. Endocrinol. Metab. 49; 34-39, 1979.

12. Georget, V., Lobaccaro, J. M., Terouanne, B., Mangeat, P., Nicolas, J. C. and Sultan, C.: Trafficking of the androgen receptor in living cells with fused green fluorescent protein-androgen receptor. Mol. Cell. Endocrinol. 129; 17-26, 1997.

13. Gorski, J. and Gannon, F.: Current models of steroid hormone action: a critique. Annu. Rev. Physiol. 38; 425-450, 1976.

14. Greene, G. L. and Press, M. F.: Structure and dynamics of the estrogen receptor. J. Steroid Biochem. 24; 1-7, 1986.

15. Grese, T. A., Sluka, J. P., Bryant, H. U., Cullinan, G. J., Glasebrook, A. L., Jones, C. D., Matsumoto, K., Palkowitz, A. D., Sato, M., Termine, J. D., Winter, M. A., Yang, N. N. and Dodge, J. A.: Molecular determinants of tissue selectivity in estrogen receptor modulators. Proc. Natl. Acad. U S A 94; 1410514110, 1997.

16. Guiochon-Mantel, A., Lescop, P., Christin-Maitre, S., Loosfelt, H., Perrot-Applanat, M. and Milgrom, E.: Nucleocytoplasmic shuttling of the progesterone receptor. EMBO J. 10; 3851-3859, 1991.

17. Hiroi, H., Watanabe, T., Goto, W., Orimo, A., Momoeda, M., Tsutumi, O., Taketani, Y. and Muramtsu, M.: Differential immunolocalization of estrogen receptor alpha and beta in rat ovary and uterus. J. Mol. Endocrinol. 22; 37-44, 1999.

18. Htun, H., Barsony, J., Reny, I., Goul, D. L. and Hager, G. L.: Visualization of glucocorticoid receptor translocation and intranuclear organization in living cells with a green fluorescent protein chimera. Proc. Natl. Acad. Sci. U S A 93; 4845-4850, 1996. 
19. Htun, H., Holth, L. H., Walker, D., Davie, J. R. and Hager, G. L.: Direct visualization of the human estrogen receptor $\alpha$ reveals a role for ligand in the nuclear distribution of the receptor. Mol. Biol. Cell 10; 471-486, 1999.

20. Ichinose, H., Garnier, J. M., Chambon, P. and Losson, R.: Ligand-dependent interaction between the estrogen receptor and the human homologues of SWI2/SNF2. Gene 188; 95-100, 1997.

21. Jans, D. A.: The regulation of protein transport to the nucleus by phosphorylation. Biochem. J. 311; 705-716, 1995.

22. Jones, P. S., Parrott, E. and White, I. N. H.: Activation of transcription by estrogen receptor $\alpha$ and $\beta$ is cell type- and promoterdependent. J. Biol. Chem. 274; 32008-32014, 1999.

23. Jung-Testas, I., Schumacher, M., Bugnard, H. and Baulieu, E. Stimulation of rat Schwann cell proliferation by estradiol: synergism between the estrogen and cAMP. Dev. Brain Res. 72; 282 290, 1993.

24. Kawata, M., Yuri, K., Ozawa, H., Nishi, M., Ito, T., Hu, Z., Lu, H. and Yoshida, M.: Steroid hormones and their receptors in the brain. J. Steroid Biochem. Mol. Biol. 65; 1-6, 1998.

25. King, J. W. and Greene, G. L.: Monoclonal antibodies localize oestrogen receptor in the nuclei of target cells. Nature 307; 745 747, 1984.

26. Kingston, R. E., Bunker, C. A. and Imbalzano, A. N.: Repression and activation by multiprotein complexes that alter chromatin structure. Genes Dev. 10; 905-920, 1996.

27. Koike, S., Sakai, M. and Muramatsu, M.: Molecular cloning and characterization of rat estrogen receptor cDNA. Nucleic Acids Res. 15; 2499-2513, 1987.

28. Krecic, A. M. and Swanson, M. S.: hnRNP complexes: composition, structure, and function. Curr. Opin. Cell Biol. 11; 363-371, 1999.

29. Kuiper, G. G. J. M., Carlsson, B., Crandien, K., Enmark, E., Haggblad, J., Nilsson, S. and Gustafsson, J. A.: Comparison of the ligand binding specificity and transcript tissue distribution of estrogen receptors $\alpha$ and $\beta$. Endocrinology 138; 863-870, 1997.

30. Kusec, V., Virdi, A. S., Prince, R. and Triffitt, J. T.: Localization of estrogen receptor- $\alpha$ in human and rabbit skeletal tissues. $J$. Clin. Endocrinol. Metab. 83; 2421-2428, 1998.

31. Lim, C. S., Baumann, C. T., Htun, H., Xian, W., Irie, M., Smith, C. L. and Hager, G. L.: Differential localization and activity of the A- and B-forms of the human progesterone receptor using green fluorescent protein chimeras. Mol. Endocrinol. 13; 366375,1999

32. Maruyama, K., Endoh, H., Sasaki-Iwaoka, H., Kanou, H., Shimaya, E., Hashimoto, S., Kato, S. and Kawashima, H.: A novel isoform of rat estrogen receptor beta with 18 amino acid insertion in the ligand binding domain as a putative dominant negative regulator of estrogen action. Biochem. Biophys. Res. Commun. 246; 142-147, 1998.

33. Matunis, M. J., Xing, J. and Dreyfuss, G.: The hnRNP F protein: unique primary structure, nucleic acid-binding properties, and subcellular localization. Nucleic Acids Res. 22; 1059-1067, 1994.

34. Nishi, M., Ogawa, H., Ito, T., Matsuda, K. and Kawata, M.: Dynamic changes in subcellular localization of mineralocorticoid receptor in living cells: In comparison with glucocorticoid receptor using dual-color labeling with green fluorescent protein spectral variants. Mol. Endocrinol. (in press)

35. Nishi, M., Takenaka, N., Morita, N., Ito, T., Ozawa, H. and Kawata, M.: Real-time imaging of glucocorticoid receptor dynamics in living neurons and glial cells in comparison with nonneural cells. Eur. J. Neurosci. 11; 1927-1936, 1999.

36. Nishida, M., Kasahara, K., Kaneko, M. and Iwasaki, H.: Establishment of a new human endometrial adenocarcinoma cell line, Ishikawa cells, containing estrogen and progesterone receptors. Acta Obst. Gynec. Jpn. 37; 1103-1111, 1985.

37. Ogawa, H., Inouye, S., Tsuji, F. I., Yasuda, K. and Umesono, K.: Localization, trafficking, and temperature-dependence of the
Aequorea green fluorescent protein in cultured vertebrate cells. Proc. Natl. Acad. Sci. U S A 92; 11899-11903, 1995.

38. Okamura, H., Yamamoto, K., Hayashi, S., Kuroiwa, A. and Muramatsu, M.: A polyclonal antibody to the rat oestrogen receptor expressed in Escherichia coli: characterization and application to immunohistochemistry. J. Endocrinol. 135; 333-341, 1992.

39. Peach, K., Webb, P., Kuiper, G. G. J. M., Nilsson, S., Gustafsson, J. A. and Kushner, P. J.: Differential ligand activation of estrogen receptors ER $\alpha$ and ER $\beta$ at AP1 sites. Science 277; 1508-1510, 1997.

40. Puymirat, J., Marchand, R. and Dussault, J. H.: Immunocytochemical localization of $\beta$ thyroid receptor in the rat cerebellum. Neurosci. Lett. 135; 239-242, 1992.

41. Reyes, J. C., Muchardt, C. and Yaniv, M.: Components of the human SWI/SNF complex are enriched in active chromatin and are associated with the nuclear matrix. J. Cell Biol. 137; 263274, 1997.

42. Schwartz, J. A. and Brooks, S. C.: Neutral mutations to three acidic AF2 residues in the mouse estrogen receptor confer agonist activity to A-ring isomers of estradiol. J. Steroid Biochem. Mol. Biol. 62; 173-184, 1997.

43. Steensel, B., Brink, M., Meulen, K., Binnendijk, E. P., Wansink, D. G., Jong, L., Kloet, E. R. and Driel, R.: Localization of the glucocorticoid receptor in discrete clusters in the cell nucleus. J. Cell Sci. 108; 3003-3011, 1995.

44. Stenoien, D. L., Mancini, M. G., Patel, K., Allegretto, E. A., Smith, C. L. and Mancini, M. A.: Subnuclear trafficking of estrogen receptor- $\alpha$ and steroid receptor coactivator-1. Mol. Endocrinol. 14; 518-534, 2000.

45. Tseng, W. C., Haselton, F. R. and Giorgio, T. D.: Mitosis enhances transgene expression of plasmid delivered by cationic liposomes. Biochim. Biophys. Acta 1445; 53-64, 1999.

46. Vazquez-Nin, G. H., Echeverria, O. M., Fakan, S., Traish, A. M., Wotiz, H. H. and Martin, T. E.: Immunoelectron microscopic localization of estrogen receptor on pre-mRNA containing constituents of rat uterine cell nuclei. Exp. Cell Res. 192; 396-404, 1991.

47. Warner, M., Nilsson, S. and Gustafsson, J. A.: The estrogen receptor family. Curr. Opin. Obstet. Gynecol. 11; 249-254, 1999.

48. Welshons, W. V., Grady, L. H., Judy, B. M., Jordan, V. B. and Preziosi, D. E.: Subcellular compartmentalization of MCF-7 estrogen receptor synthesis and degradation. Mol. Cell. Endocrinol. 94; 183-194, 1993.

49. Welshons, W. V., Cormier, E. M., Wolf, M. F., Williams, P. O. and Jordan, V. C.: Estrogen receptor distribution in inoculated breast cancer cell lines. Endocrinology 122; 2379-2386, 1988.

50. Yamashita, S.: Intranuclear localization of hormone-occupied and -unoccupied estrogen receptors in the mouse uterus: application of $1 \mathrm{~nm}$ immunogold-solver enhancement procedure to ultrathin frozen sections. J. Electron Microsc. 44; 22-29, 1995.

51. Ylikomi, T., Bocquel, M. T., Berry, M., Gronemeyer, H. and Chambon, P.: Cooperation of proto-signals for nuclear accumulation of estrogen and progesterone receptors. EMBO J. 11; 36813694, 1992.

52. Yokosuka, M., Okamura, H. and Hayashi, S.: Postnatal development and sex difference in neurons containing estrogen receptor$\alpha$ immunoreactivity in the preoptic brain, the diencephalon, and the amygdala in the rat. J. Comp. Neurol. 389; 81-93, 1997.

53. Yuri, K. and Kawata, M.: Nuclear localization of estrogen receptor-immunoreactivity in the preoptic area of female rats and its reduction by intraventricular colchicine treatment. Neurosci. Lett. 142; 135-138, 1992.

54. Zhu, X. G., Hanover, J. A., Harger, G. L. and Cheng, S.: Hormone-induced translocation of thyroid hormone receptors in living cells visualized using a receptor green fluorescent protein chimera. J. Biol. Chem. 273; 27058-27063, 1998. 